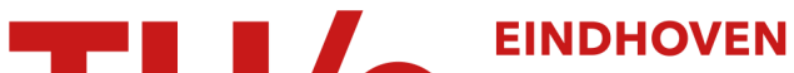 \\ UNIVERSITY OF \\ TECHNOLOGY
}

\section{High-temperature nitridation of Ni-Cr alloys}

Citation for published version (APA):

Kodentsov, A., Gülpen, J. H., Cserhati, C., Kivilahti, J., \& Loo, van, F. J. J. (1996). High-temperature nitridation of Ni-Cr alloys. Metallurgical and Materials Transactions A: Physical Metallurgy and Materials Science, 27(1),

59-69. https://doi.org/10.1007/BF02647747

DOI:

10.1007/BF02647747

Document status and date:

Published: 01/01/1996

\section{Document Version:}

Publisher's PDF, also known as Version of Record (includes final page, issue and volume numbers)

\section{Please check the document version of this publication:}

- A submitted manuscript is the version of the article upon submission and before peer-review. There can be important differences between the submitted version and the official published version of record. People interested in the research are advised to contact the author for the final version of the publication, or visit the $\mathrm{DOI}$ to the publisher's website.

- The final author version and the galley proof are versions of the publication after peer review.

- The final published version features the final layout of the paper including the volume, issue and page numbers.

Link to publication

\section{General rights}

Copyright and moral rights for the publications made accessible in the public portal are retained by the authors and/or other copyright owners and it is a condition of accessing publications that users recognise and abide by the legal requirements associated with these rights.

- Users may download and print one copy of any publication from the public portal for the purpose of private study or research.

- You may not further distribute the material or use it for any profit-making activity or commercial gain

- You may freely distribute the URL identifying the publication in the public portal.

If the publication is distributed under the terms of Article $25 \mathrm{fa}$ of the Dutch Copyright Act, indicated by the "Taverne" license above, please follow below link for the End User Agreement:

www.tue.nl/taverne

Take down policy

If you believe that this document breaches copyright please contact us at:

openaccess@tue.nl

providing details and we will investigate your claim. 


\title{
High-Temperature Nitridation of Ni-Cr Alloys
}

\author{
A.A. KODENTSOV, J.H. GÜLPEN, C. CSERHÁTI, J.K. KIVILAHTI, and F.J.J. VAN LOO
}

The nitriding behavior of nickel-chromium alloys was investigated at $1398 \mathrm{~K}$ over the range 1 to $6000 \mathrm{bar}$ of external nitrogen pressure. The morphology of the nitrided zone depends on the concentration of chromium in the initial alloy, and the $\mathrm{N}_{2}$ pressure (fugacity) applied upon the system. The transition from $\mathrm{CrN}$ to $\mathrm{Cr}_{2} \mathrm{~N}$ precipitation was observed within the reaction zone after nitriding at 100 to 6000 bar of $\mathrm{N}_{2}$ when the chromium content in the initial alloys was 28.0 at. pct or higher. peritectoid reaction between $\mathrm{Cr}_{2} \mathrm{~N}$ and nickel solid solútion and becomes unstable above $1373 \mathrm{~K}$. The thermodynamic evaluation of the $\mathrm{Ni}-\mathrm{Cr}-\mathrm{N}$ system was performed and phase equilibria calculated. Evidence for "up hill" diffusion of nitrogen near the reaction front during the internal nitridation of $\mathrm{Ni}-\mathrm{Cr}$ alloys at $1398 \mathrm{~K}$ was found. It was attributed to the relative instability of chromium nitrides and strong Cr-N interaction in the matrix of the Ni-based solid solution within the nitrided zone

\section{INTRODUCTION}

WHEN a homogeneous binary alloy $\mathrm{A}-\mathrm{B}$ is heated in nitriding atmosphere (e.g., a mixture of $\mathrm{NH}_{3}+\mathrm{H}_{2}, \mathrm{~N}_{2}$, etc. ), selective nitridation may take place if the external activity of nitrogen is sufficient to nitridize $B$ (solute) but not $A$. Nitrogen can react with the solute to form a surface nitride layer. However, if the permeation of nitrogen into the metal $A$ is appreciable, the precipitation of the solute $B$ (in the form of nitrides) may also occur inside the alloy. Whether exclusive surface nitridation or formation of internal precipitates (or a combination of both) takes place depends on the activity of nitrogen in the surrounding atmosphere, the activity of the solute $B$ in the matrix of solid solution $A(B)$; and the relative diffusivities of nitrogen and the solute el ement in the solid solution $A(B)$

Most studies on nitriding behavior have been performed on ferrous alloys. Nitriding of iron-based alloys is a wellknown and widely used commercial process. Internal nitridation of nickel-based alloys, however, was first reported by Barnes and Lai only a few years ago. Later, Rubly and Douglass ${ }^{[2]}$ studied the nitriding behavior of nickel-chromium alloys in an ammonia-hydrogen mixture over the range of 973 to $1173 \mathrm{~K}$. Internal nitridation rates for dif ferent $\mathrm{Ni}$-Cr alloys were found to obey the parabolic time dependency law and decreased with increasing chromium content. The aims of the present work were as follows:

(1) to investigate the interaction of $\mathrm{Ni}-\mathrm{Cr}$ alloys with $\mathrm{ni}$ trogen at different external pressures $(1$ to 6000 bar of $\mathrm{N}_{2}$ ) at $1398 \mathrm{~K}$; and

(2) to evaluate the internal nitriding of Ni-Cr alloys using a thermodynamic assessment of the $\mathrm{Ni}-\mathrm{Cr}-\mathrm{N}$ system.

A.A. KODENTSOV, Researcher, J.H. GÜLPEN, Postdoctorat Student, and F.J.J. VAN LOO, Professor, are with the Laboratory of Solid State Chemistry and Materials Science, Eindhoven University of Technology, $5600 \mathrm{MB}$ Eindhoven, The Netherlands. C. CSERHÁTI, Researcher, is with the Department of Solid State Physics, Kossuth Lajos University, $H_{-}^{-}$ 4010 Debrecen, Hungary. J.K. KIVIAHTI, Professor, is with the Department of Materials Science and Engineering, Helsinki University of Technology, 02150 Espoo, Finland.

Manuscript submitted March 10, 1994.

\section{EXPERIMENTAL PROCEDURE}

High-purity nickel (99.98) and chromium (99.95) were used as initial materials. Ni-Cr alloys (5.0 to 32.0 at. pet of $\mathrm{Cr}$ ) were melted in an arc furnace under argon atmosphere using a nonconsumable tungsten electrode. The ingots were cold-rolled to a thickness of $1.5 \mathrm{~mm}$. Slices of $8 \times 8 \mathrm{~mm}$ were cut from the sheets and homogenized for 100 hours at 1 bar of gas mixture $\mathrm{Ar}+10$ vol pct $\mathrm{H}_{2}\left(\mathrm{H}_{2} \mathrm{O} \leq 5 \mathrm{ppm}\right)$ and $1373 \mathrm{~K}$. The grain size in the final materials was in the range of 100 to $150 \mu \mathrm{m}$.

Nitriding of the alloys at 1 bar of nitrogen was performed in a vacuum furnace equipped with a gas inlet system which enabled heat treatment in isostatic gas conditions. If quenching of the sample was necessary, a horizontal tube furnace with flowing nitrogen was used In experiments performed at 1 bar of $\mathrm{N}_{2}$ pressure, the temperature was controlled within \pm 3 deg.

For total gas pressures up to $100 \mathrm{bar}$, a sintering firnace (KCE, Germany) was used. Temperature control was carritied out with an optical pyrometer with an accuracy of \pm 5 deg.

Nitridation at 900 to 6000 bar was performed in ultrahigh pressure equipment made by UNIPRESS (Poland). Pressure of $\mathrm{N}_{2}$ was controlled by using a manganine gauge within \pm 10 bar accuracy. Temperature control was carried out within \pm 2 deg accuracy. More technical details concerning the ultrăhigh pressure equipment can be found elsewhere. [3]

All nitriding experiments were performed in pure nitrogen $\left(\mathrm{O}_{2} \leq 10 \mathrm{ppm} ; \mathrm{H}_{2} \mathrm{O} \leq 10 \mathrm{ppm}\right)$. Before the nitriding run under isostatic conditions, the furnaces were evacuated up to $10^{-4}$ mbar, filled with pure nitrogen, and evacuated again. After nitridation under these conditions, no oxide formation was detected with X-ray diffraction (XRD) analysis at the surface of the samples.

The cooling rate in all experiments was $600 \mathrm{deg} / \mathrm{h}$. Only in experiments carried out at 1 bar of $\mathrm{N}_{2}$ did this rate vary, from 75 to $600 \mathrm{deg} / \mathrm{h}$.

The surfaces of the alloys after nitriding were examined by XRD analysis with a cylindrical texture camera using nickel-filtered $\mathrm{Cu} K_{\alpha}$ radiation. ${ }^{[4]}$ The strong intensity modulation of the diffraction lines of the $\mathrm{Ni}$, Cr-substrate are due to the coarse structure of the alloys (grain size $>100 \mu \mathrm{m}$ ). 


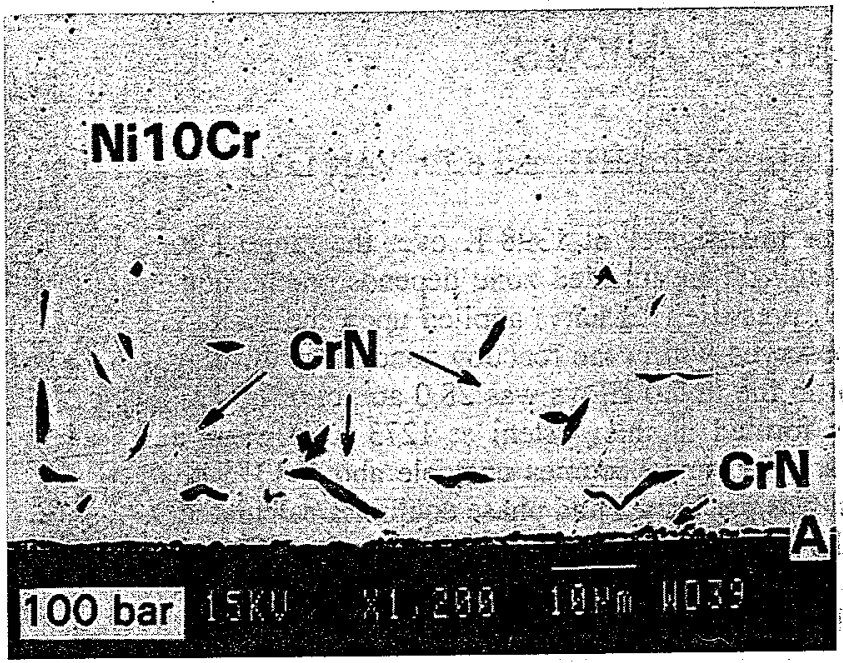

(a)

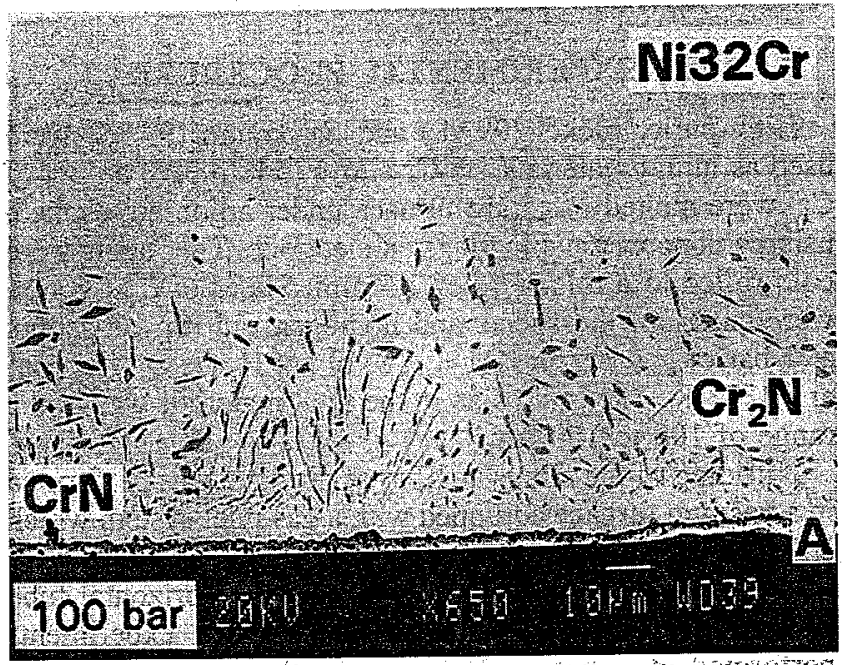

(b)

Fig. 1-Secondary electron images of the reaction zone after nitriding of various , Ni-Cr alloys, $(a) \mathrm{Ni}-10 \mathrm{Cr}$ and $(b) \mathrm{Ni}-32 \mathrm{Cr}$, at $1398 \mathrm{~K}$ and 100 bar of nitrogen for $4 \mathrm{~h}(\mathrm{~A}=$ metal-gas interface).

The formation of the nitride phases on the metal surface was revealed by the continuous lines of cubic $\mathrm{CrN}(\mathrm{Fm} \overline{3} \mathrm{~m})$ or hexagonal $\mathrm{Cr}_{2} \mathrm{~N}(\mathrm{P} \overline{3} 1 \mathrm{~m})$ in the diffraction pattern.

Then the nitrided samples were cross sectioned and, after standard metallographic preparation, investigated by optical microscopy, scanning electron microscopy (SEM), and electron probe microanalysis (EPMA). The types of internal precipitates which were observed inside the alloys were determined with the aid of transmission electron microscopy (TEM). Samples were prepared by mechanical thinning and dimple grinding; electron-beam transparency was accomplished by $6 \mathrm{kV}$ argon-ion milling.

\section{RESULTS}

\section{A. Morphology of the Diffusion Zone after Nitriding at $100 \mathrm{Bar}$ of $\mathrm{N}_{2}$ and $1398 \mathrm{~K}$}

After nitriding of the $\mathrm{Ni}-\mathrm{Cr}$ alloys containing 10.0 to 32.0 at. pct of $\mathrm{Cr}$ at $1398 \mathrm{~K}$ at 100 bar of nitrogen, the reaction zone consists of a surface layer of $\mathrm{CrN}$ and nitride precipitates inside the alloys. In Figures $1(\mathrm{a})$ and (b), the microstructures of the nitrided zone in the various $\mathrm{Ni}-\mathrm{Cr}$ alloys are given. A characteristic feature of the nitrided zone is the presence of a precipitate-free layer of the $\mathrm{Ni}-\mathrm{Cr}$ solid solution between the-surface nitride layer and the zone of internal precipitates.

The type of the internal precipitates (cubic $\mathrm{CrN}$ or hexagonal $\mathrm{Cr}_{2} \mathrm{~N}$ ) which can be formed after nitriding under these conditions depends on the concentration of chromium in the initial substrate. Electron diffraction gave positive identification of cubic $\mathrm{CrN}$ in the $\mathrm{Ni}-\mathrm{Cr}$ matrix with an initial chromium content up to 22.0 at. pct and of hexagonal $\mathrm{Cr}_{2} \mathrm{~N}$ for alloys with a $\mathrm{Cr}$ content $\geq 28.0$ at. pct when the sample was taken from the central part of the nitrided zone (Figures 2 and 3). However, at the edges of the nitrided sample, the formation of both $\mathrm{CrN}$ and $\mathrm{Cr}_{2} \mathrm{~N}$ precipitates was observed (Figure 4). The average concentration of chromium in the solid solution, which is in equilibrium with both $\mathrm{CrN}$ and $\mathrm{Cr}_{2} \mathrm{~N}$, was $23.8 \pm 0.5$ at. pct (point $\mathrm{C}$ in Figure 4).

\section{B. Nitriding of Ni-Cr Alloys at 900 Bar of Nitrogen and $1398 \mathrm{~K}$}

With increasing external nitrogen pressure (up to 900 bar), the process of internal nitridation becomes more pronounced. Various types of microstructure in the diffiusion zone after nitridation at $1398 \mathrm{~K}$ and 900 bar of $\mathrm{N}_{2}$ are given in Figures 5(a) and (b).

Exclusive internal nitridation in the absence of surface nitride layer formation occurs in the alloy with 5.0 at. pct of chromium. The reaction zone consisted of numerous isolated precipitates of $\mathrm{CrN}$ with an orientation relationship tô the matrix phase (Figure 5(a))

$A$ surface layer of $\mathrm{CrN}$ with internal nitride precipitates was found in the alloys with higher $\mathrm{Cr}$ contents $\mathrm{A}$ thin precipitate-free zone of $\mathrm{Ni}$-Cr solid solution was observed between the surface layer and a zone of internal precipitates. Quite large, angular particles of $\mathrm{CrN}$ were found near the precipitate-free zone. Deeper in the alloy; the reaction zone consists of particles inside the grains and along grain bound aries of the $\mathrm{Ni}-\mathrm{CP}$ matrix. Precipitation along grain boundaries was found even beyond the nitrided front. The reaction front in samples after nitriding at $1398 \mathrm{~K}$ and $\mathrm{a}$ pressuure of 900 bar of nitrogen was nonplanar Attempts to study the kinetics of the nitrided zone growth were inconclusive.

When the chromium content in the initial alloy was increased to 28.0 at pct, the formation of both cubic $\mathrm{CrN}$ and hexagonal $\mathrm{Cr}_{2} \mathrm{~N}$ was observed within the reaction zone (Figures $5(\mathrm{~b})$ and 6). Under these experimental conditions, the transition from $\mathrm{CrN}$ to $\mathrm{Cr}_{2} \mathrm{~N}$ precipitation takes place along the whole nitrided zone. The concentrations of chromium in the solid solution, which is in equilibrium with both $\mathrm{CrN}$ and $\mathrm{Cr}_{2} \mathrm{~N}$ precipitates (e.g., point $\mathrm{C}$ in Figure 6), are listed in Table I.

\section{Internal Nitridation at 6000 Bar of Nitrogen and 1398 $K$}

When an extremely high pressure of nitrogen of 6000 bar was applied upon the system, the exclusive internal nitridation in the absence of the surface nitride layer was 


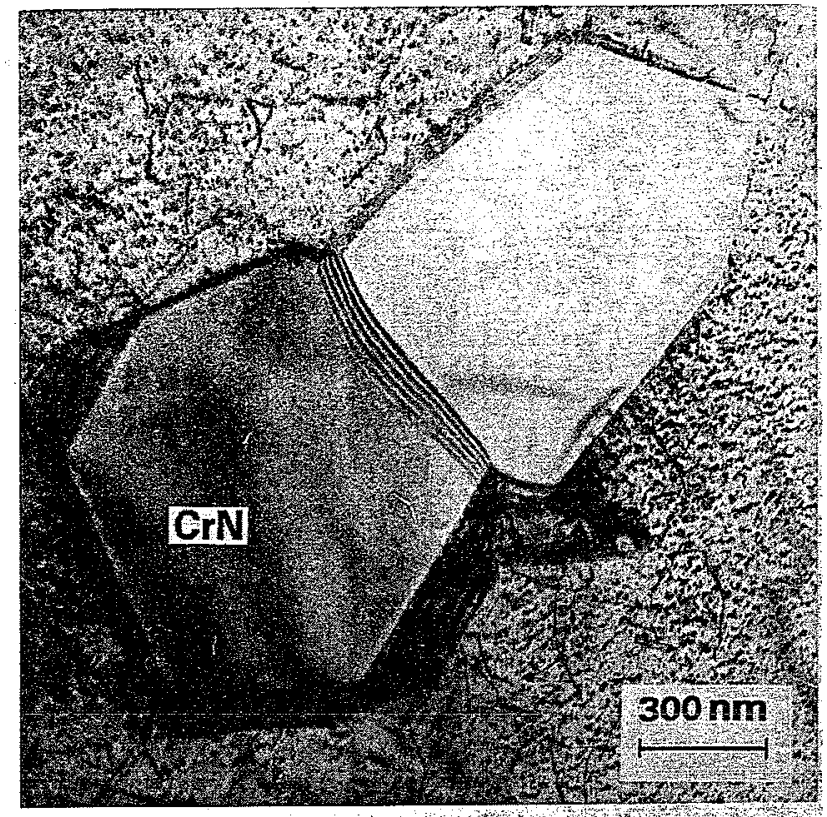

(a)

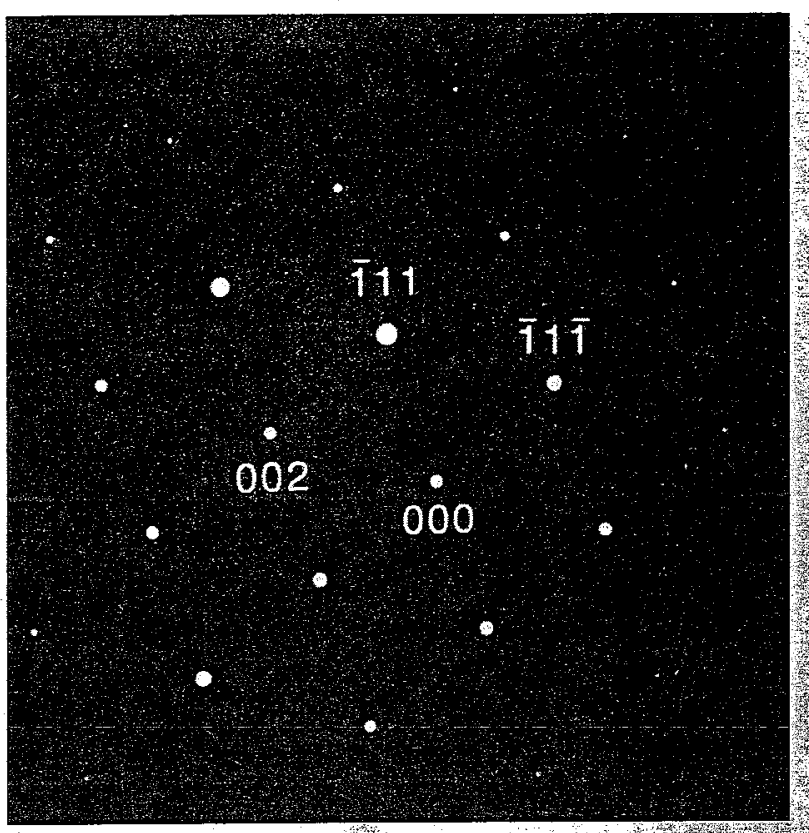

(b)

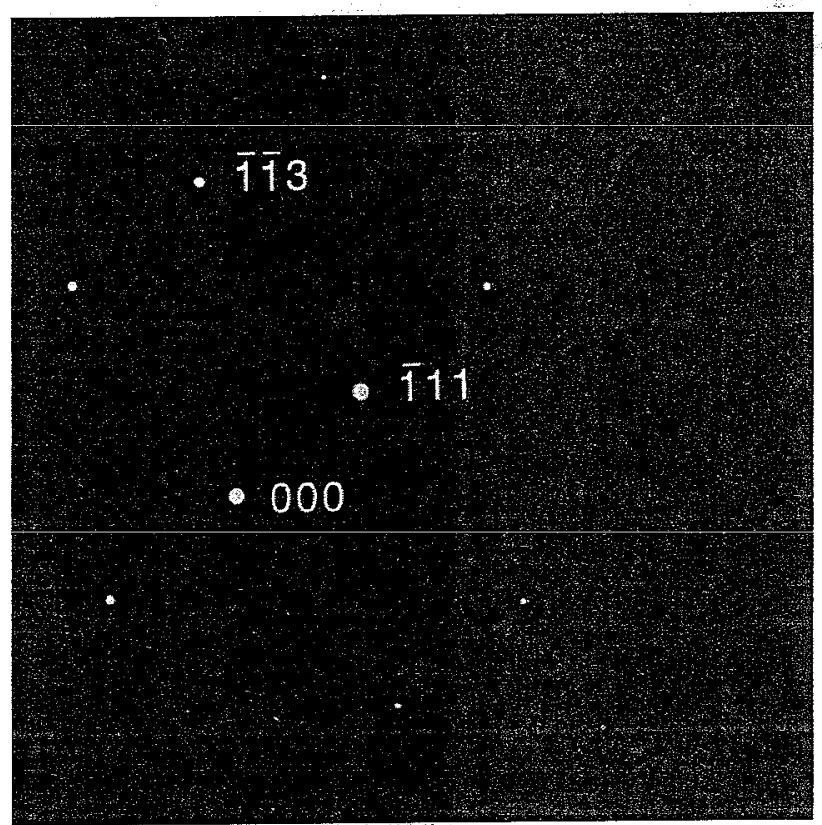

$\mathrm{H}^{2}, \mathrm{c}(c)$

Fig. 2 - (a) Bright-field image and selected area diffraction patterns taken from the nitride particle formed inside the $\mathrm{Ni}-22 \mathrm{Cr}$ alloy upon nitriding at 100 bar of $\mathrm{N}_{2}(1398 \mathrm{~K}, 4 \mathrm{~h})$ indexed as $(b)$ [110] and (c) [211] directions in the cubic lattice of CrN (Fm $\overline{3} \mathrm{~m}, a=0.4148 \mathrm{~nm}$ ).

observed in the alloys with the chromium content up to 15.0 at. pct (Figures 7(a) and (b)). The morphology of the nitrided zone was somewhat similar to that described by Douglass for the case of nitriding Ni-Cr alloys from a mixture of $\mathrm{NH}_{3}+\mathrm{H}_{2}$ in the temperature range 973 to 1173 $\mathrm{K}{ }^{[2]}$ Internal precipitates near the metal-gas interface were small and generally rounded, becoming coarser with increasing depth.

With increasing chromium content in the initial alloy up to 22.0 at. pct, the formation of the surface layer of $\mathrm{CrN}$ and internal nitride precipitates was found. Relatively small, rounded precipitates of $\mathrm{CrN}$ were formed close to the surface nitride layer. Deeper in the alloy, precipitates became coarser and transformed to a "Widmanstätten"' type structure of relatively large, angular precipitates. In some areas of the diffusion zone, precipitates had a blocky morphology, especially in the matrix with a high initial $C r$ content (Figure 8(a)).Deeper into the alloy, intergranulàr nitride formation with plate-type particles inside of grains was observed. The internal nitridation boundary was not sharp, which made it difficult to get reliable kinetic data.

The transition from $\mathrm{CrN}$ to $\mathrm{Cr}_{2} \mathrm{~N}$ precipitation within the 

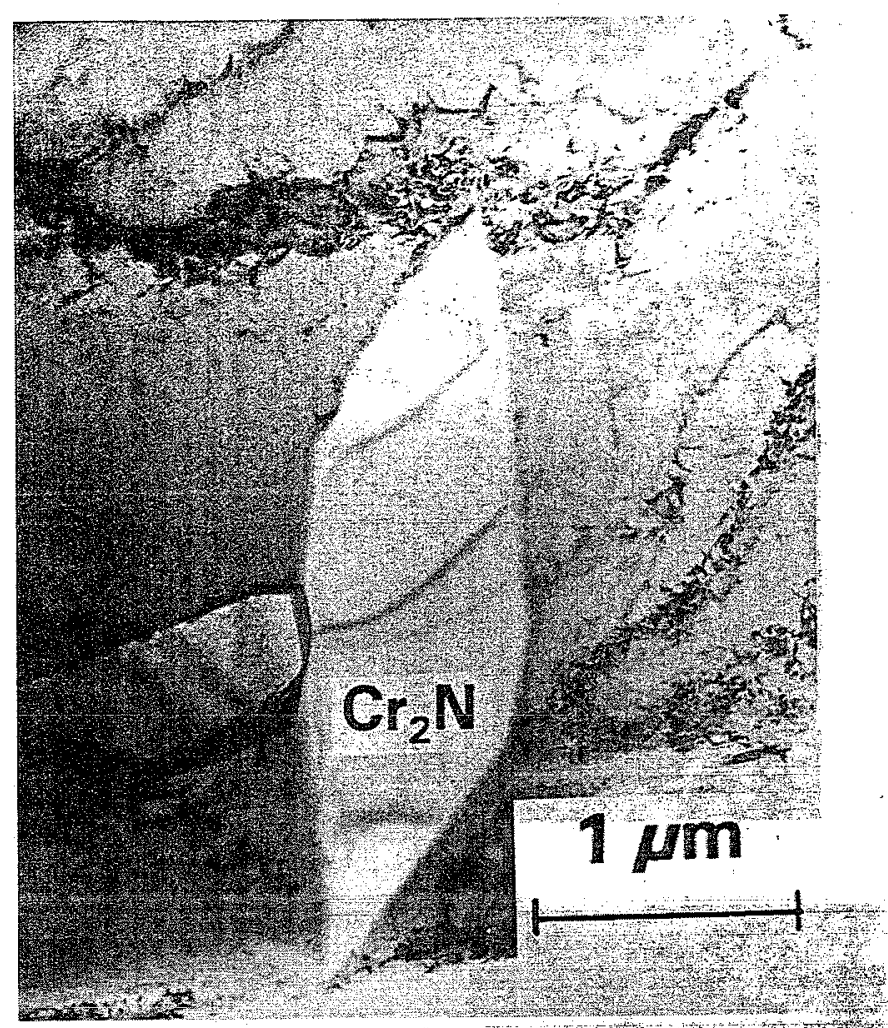

(a)

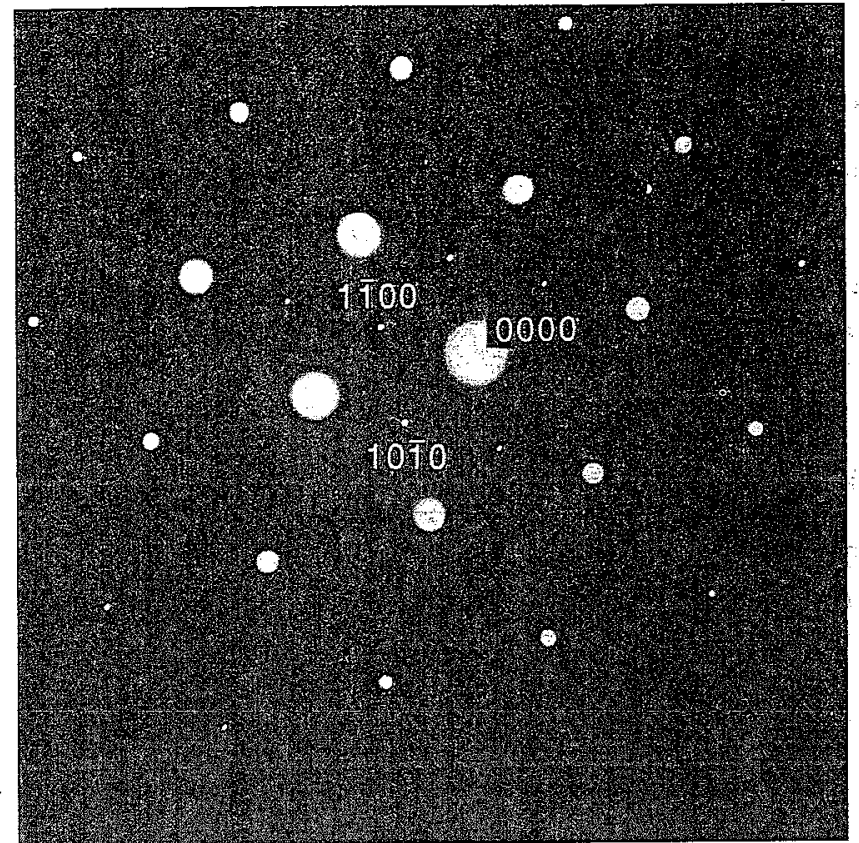

(b)

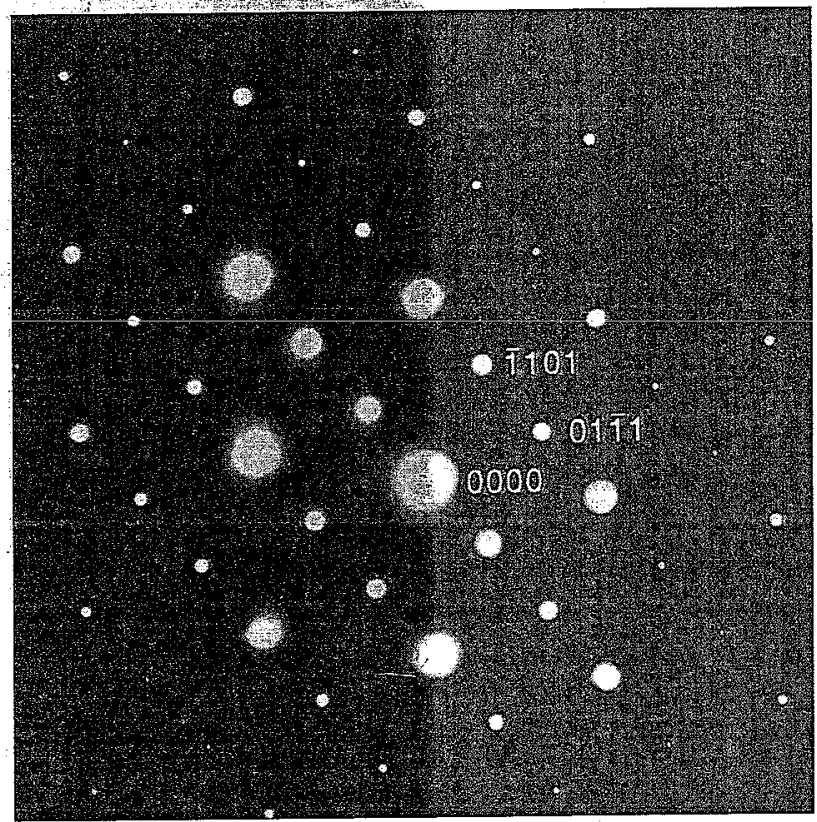

(c)

Fig. 3- (a) Bright-field image and selected area diffraction pattems taken from the nitride particles formed inside the $\mathrm{Ni}-28 \mathrm{Cr}$ alloy after nitriding at 100 bar of $\mathrm{N}_{2}(1398 \mathrm{~K}, 4 \mathrm{~h})$ indexed as $(b)$ [0001] and $(c)$ [12.13] direction in the hexagonal lattice of $\mathrm{Cr}_{2} \mathrm{~N}(\mathrm{P} 31 \mathrm{~m}, a=0.481 \mathrm{~nm}, c=0.4484 \mathrm{~nm})$. Sample for TEM was prepared from the central part of the nitrided zone.

diffusion zone was again clearly visible at a $\mathrm{Cr}$ content in the initial alloys of 28.0 at. pct and higher (Figures 8(a) and (b)). The average composition of the $\mathrm{Ni}-\mathrm{Cr}$ solid solution which is in equilibrium with $\mathrm{CrN}$ and $\mathrm{Cr}_{2} \mathrm{~N}$ precipitates (point $\mathrm{C}$ in Figure 8(b)) was found as $24.3 \pm 0.3$ and $24.6 \pm 0.5$ at. pct of $\mathrm{Cr}$ for $\mathrm{Ni}-\mathrm{Cr}$ alloys with 28.0 and 32.0 at. pet of chromium, respectively.

\section{Phase Formation in the System Ni-Cr Alloy-Nitrogen at External Pressure of 1 Bar}

Only the hexagonal nitride $\mathrm{Cr}_{2} \mathrm{~N}$ was detected at the surface and inside the $\mathrm{Ni}-\mathrm{Cr}$ alloys with a chromium content more than 28.0 at. pct after annealing at $1398 \mathrm{~K}$ and 1 bar of $\mathrm{N}_{2}$ when samples were cooled down quite fast (about 


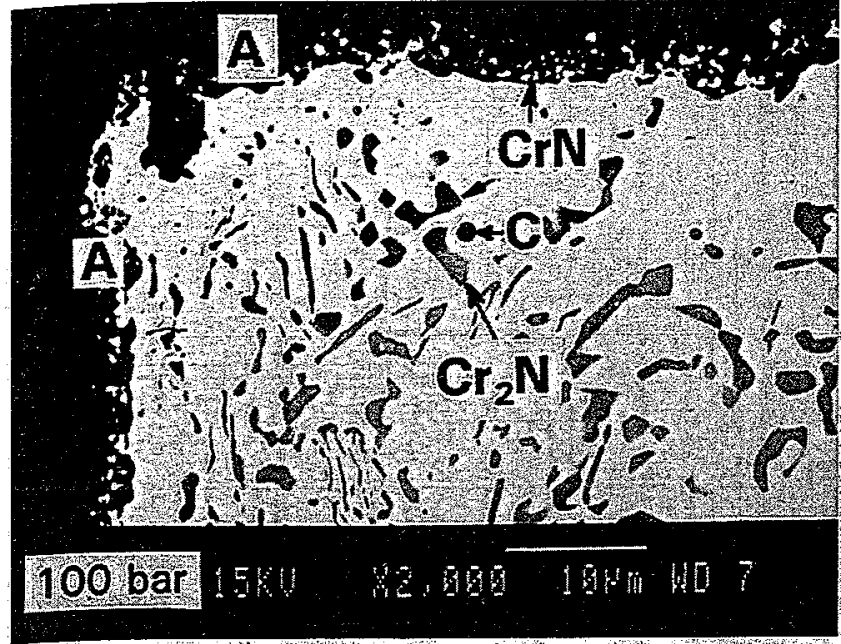

Fig. 4-Backscattered electron image of a $\mathrm{Ni}$ alloy with 32.0 at. pet of Cr nitrided at 100 bar of $N_{2}$ and $1398 \mathrm{~K}$ for $4 \mathrm{~h}$ showing the formation of $\mathrm{CrN}$ precipitates at the edge of the sample $(\mathrm{A}=$ metal-gas interface $)$. Point $C$ indicates alloy in equilibrium with $C r N$ and $\mathrm{Cr}_{2} \mathrm{~N}$.

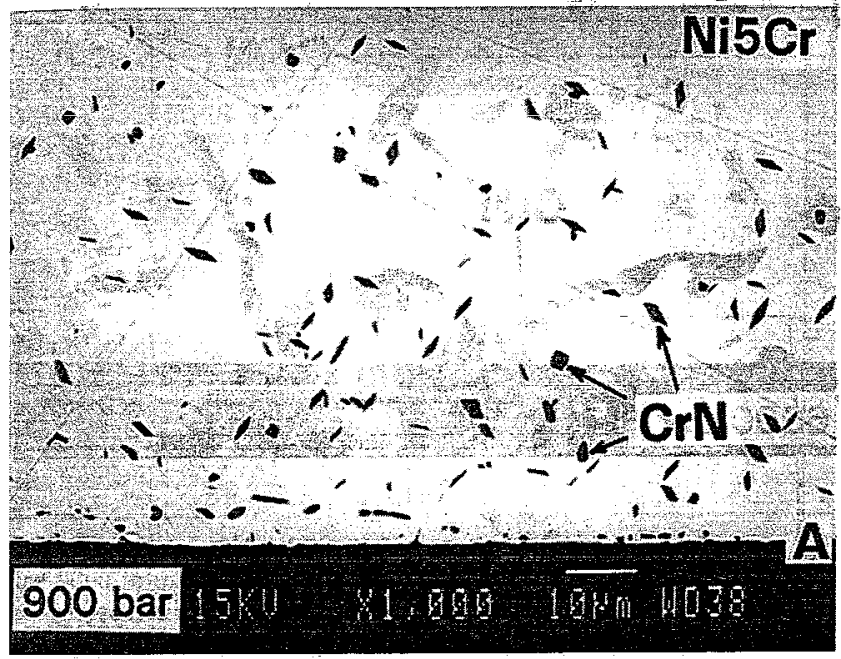

(a)

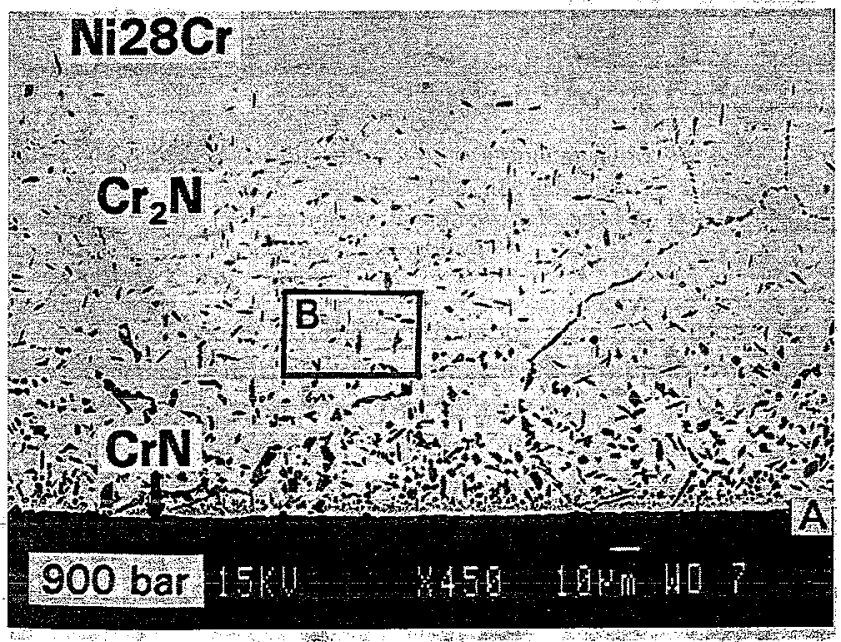

(b)

Fig. 5-Backscattered electron images of the nitrided zone in different $\mathrm{Ni}-\mathrm{Cr}$ alloys after annealing at $1398 \mathrm{~K}$ and 900 bar of $\mathrm{N}_{2}$ for $4 \mathrm{~h}:(a) \mathrm{Ni}-$ $5 \mathrm{Cr}$ and $(b) \mathrm{Ni}-28 \mathrm{Cr}(\mathrm{A}=$ metal-gas interface).

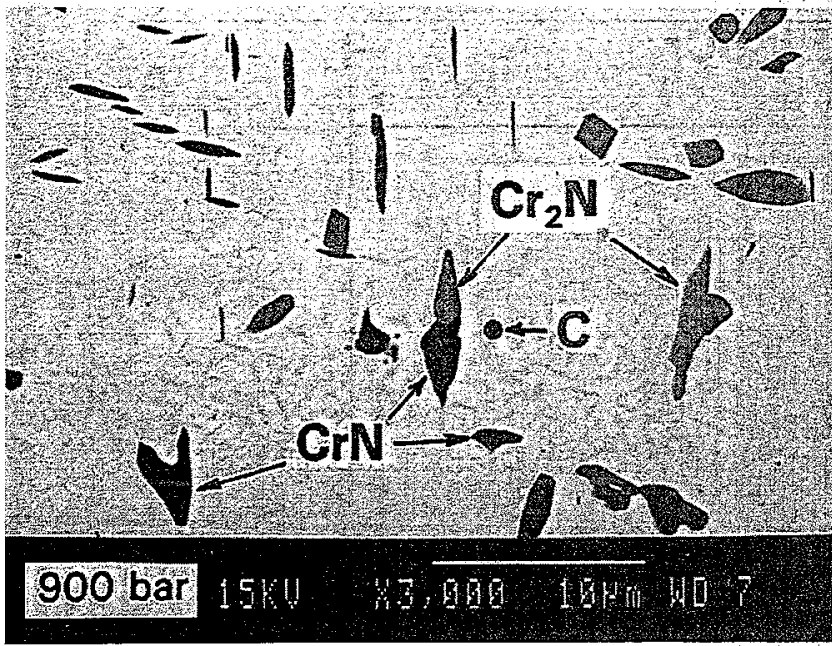

Fig. 6-Backscattered electron image showing the transition from $\mathrm{CrN}$ to $\mathrm{Cr}_{2} \mathrm{~N}$ precipitates within the nitrided zone. Micrograph represents the magnified area $\mathrm{B}$ in Fig. $5(\mathrm{~b})$.

Table I. Composition of the Ni-Cr Solid Solution in Equilibrium with $\mathrm{CrN}$ and $\mathrm{Cr}_{2} \mathrm{~N}$ Precipitates in the Nitrided Zone after Annealing at $1398 \mathrm{~K}$ at $900 \mathrm{Bar}$ of $\mathrm{N}_{2}$

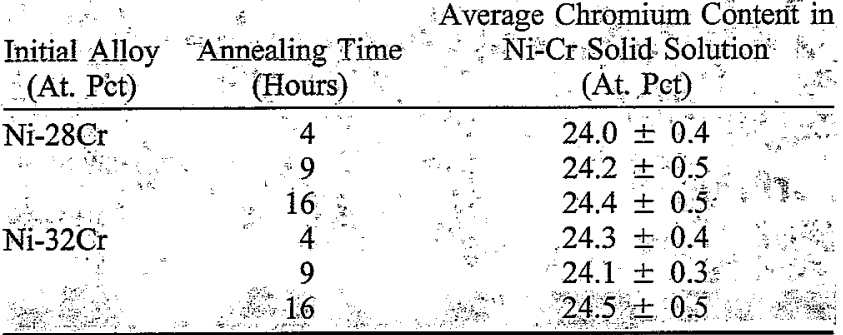

500 to $600 \mathrm{deg} / \mathrm{h}$ ). Grain boundary precipitation of $\mathrm{Cr}_{2} \mathrm{~N}$ and plate-type precipitates inside the grains was observed. A typical microstructure of the diffusion zone in the samples after heat treatment under these conditions is shown in Figure 9.

However, with a decreasing cooling rate up to $300 \mathrm{deg} / \mathrm{h}$, the formation of a ternary phase of the Ni-Cr-N system inside the $\mathrm{Ni}-\mathrm{Cr}$ alloy was found (Figure 10 ). Probably; this ternary phase is the same nitride phase that was reported by Kikuchi and designated as a $\pi$ phase. ${ }^{[5 ; 6]}$. He made a conclusion that the $\pi$ phase in $\mathrm{Ni}-\mathrm{Cr}-\mathrm{N}$ system has the metal-atom arrangement of $\beta$-manganese and may be formed at $1273 \mathrm{~K}$ through a peritectoid reaction between dichromium nitride $\mathrm{Cr}_{2} \mathrm{~N}$ and the nickel solid solution. This possibility seems to be confirmed by the morphology of the reaction zone after nitridation of nickel alloy with $32: 0$ at. pet of $\mathrm{Cr}$ at 1 bar of $\mathrm{N}_{2}$ and slow cooling ( 75 to $300 \mathrm{deg} / \mathrm{h}$ ) (Figure 10). A rim of the $\pi$ phase around nitride particles indicates that a peritectoid reaction between the $\mathrm{Ni}-\mathrm{Cr}$ solid solution and chromium nitride may occur upon cooling. After subsequent annealing of such a sample at $1398 \mathrm{~K}$ and 1 bar of nitrogen and quenching, the $\pi$ phase has disappeared completely. However, the $\pi$ phase was still detected in the nitrided zone of the samples quenched after a heat treatment at $1273 \mathrm{~K}$ and 1 bar of $\mathrm{N}_{2}$. In general, the present results are consistent with the experimental data of Kikuchi and co-workers ${ }^{[5,6]}$ and the thermodynamic assessments of the Ni-Cr-N system performed by Frisk. ${ }^{[7]}$ They agreed that 


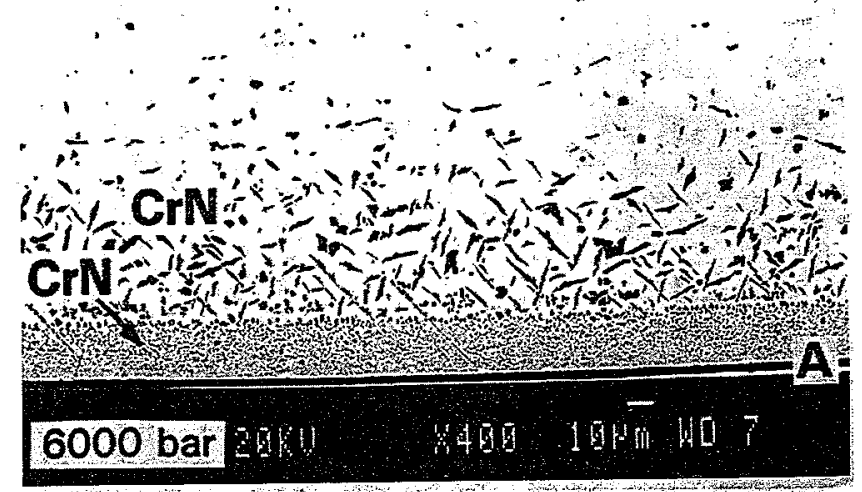

(a)

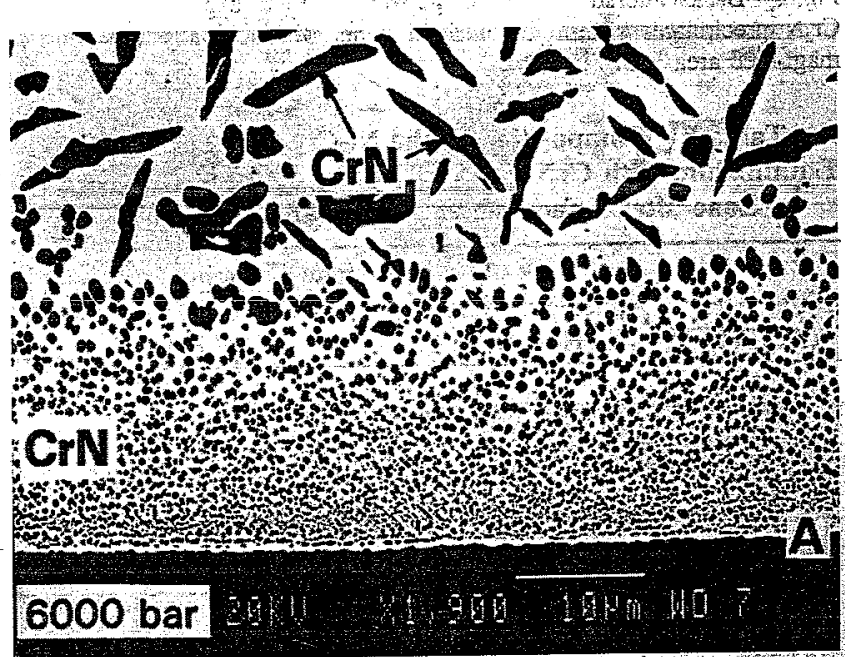

(b)

Fig. 7-Backscattered electron images of the reaction zone after nitriding a Ni alloy with 15.0 at. pet of chromium at $1398 \mathrm{~K}$ and 6000 bar of $\mathrm{N}_{2}$ for $4 \mathrm{~h}$ : $(a)$ general view and $(b)$ variation in precipitate morphology (A $=$ metal-gas interface).

the $\pi$ phase exists as an equilibrium phase at temperatures below $1273 \mathrm{~K}$ and becomes unstable at higher temperature

The chemical composition of the $\pi$ phase was determined by Kikuchi using EPMA to be $\mathrm{Cr}_{13} \mathrm{Ni}_{7} \mathrm{~N}_{4}{ }^{[5]} \mathrm{How}$ ever, microprobe measurements performed in the present study gave slightly different results. The composition of the $\pi$ phase formed inside the Ni-Cr alloy with 32.0 at pct of $\mathrm{Cr}$ after nitridation at $1398 \mathrm{~K}$ (1 bar of $\left.\mathrm{N}_{2}\right)$, subsequent annealing at $1273 \mathrm{~K}$ and 1 bar of nitrogen, and quenching was found to be $\mathrm{Cr}_{10} \mathrm{Ni}_{7} \mathrm{~N}_{3}$. Most likely, such a difference can be attributed to the existence of a certain homogeneity range of the ternary $\pi$ phase in the $\mathrm{Ni}-\mathrm{Cr}-\mathrm{N}$ system.

\section{DISCUSSION}

\section{A. Surface Nitridation of $\mathrm{Ni}$-Cr Alloys at $1398 \mathrm{~K}$}

Phase equilibria in the $\mathrm{Ni}-\mathrm{Cr}-\mathrm{N}$ system were calculated using the latest thermodynamic evaluations of the pure components. ${ }^{[8]}$ The binary $\mathrm{Ni}-\mathrm{Cr}$; $\mathrm{Ni}-\mathrm{N}$, and $\mathrm{Cr}-\mathrm{N}$ systems were calculated using primarily the data of Frisk. ${ }^{[7]}$ The

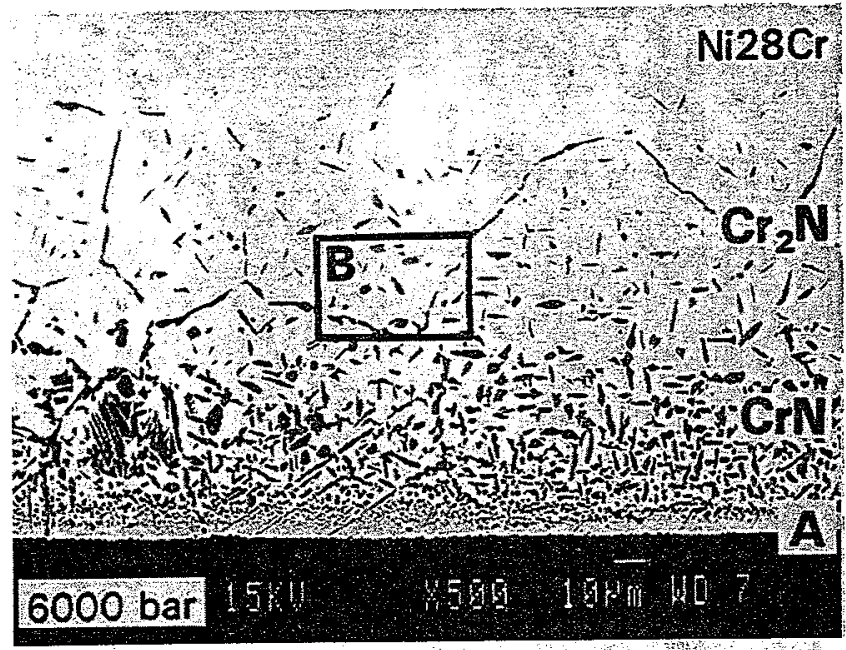

(a)

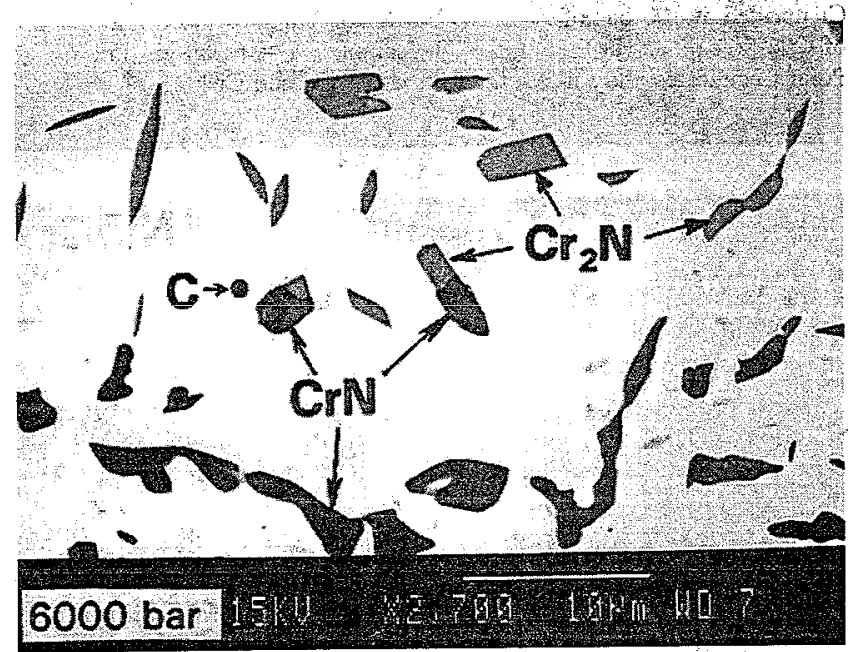

(b)

Fig. 8-Backscattered electron image of the diffusion zone after nitriding a $\mathrm{Ni}$ alloy with 28.0 at. pct of $\mathrm{Cr}$ at $1398 \mathrm{~K}$ and a pressure of $6000 \mathrm{bar}$ of $\mathrm{N}_{2}$ for $4 \mathrm{~h}$ : (a) general view and (b) magnified area $\mathrm{B}$ in showing the transition from $\mathrm{CrN}$ to $\mathrm{Cr}_{2} \mathrm{~N}$ precipitates $(\mathrm{A}=$ metal-gas interface $)$

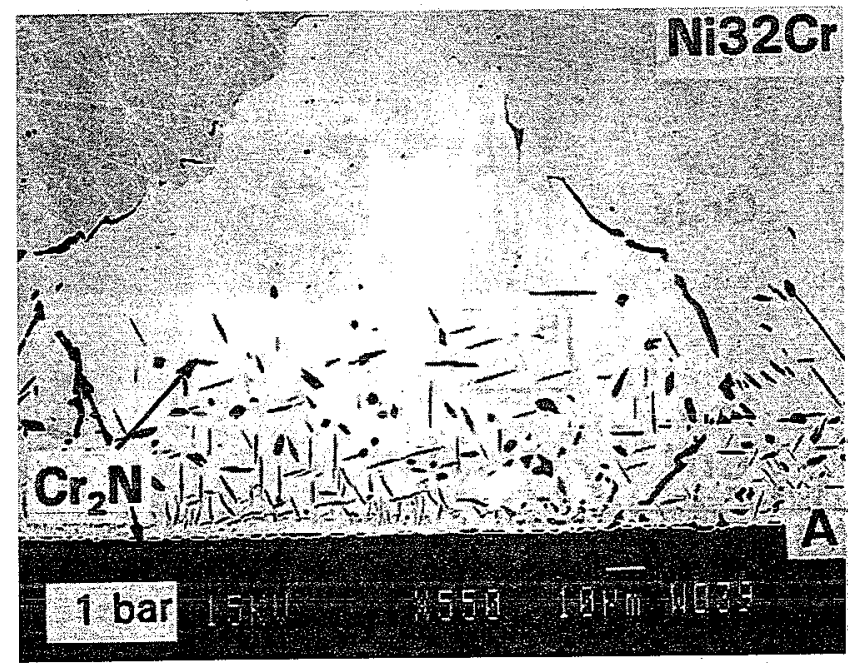

Fig. 9-Typical microstructure of the diffusion zone in the $\mathrm{Ni}-32 \mathrm{Cr}$ alloy after nitriding at $1398 \mathrm{~K}$ and 1 bar of $N_{2}$ for $16 \mathrm{~h}$ and fast cooling ( 600 $\mathrm{deg} / \mathrm{h})$ in the furnace at 1 bar of $\mathrm{N}_{2}$. Secondary electron image $(\mathrm{A}=$ metalgas interface). 


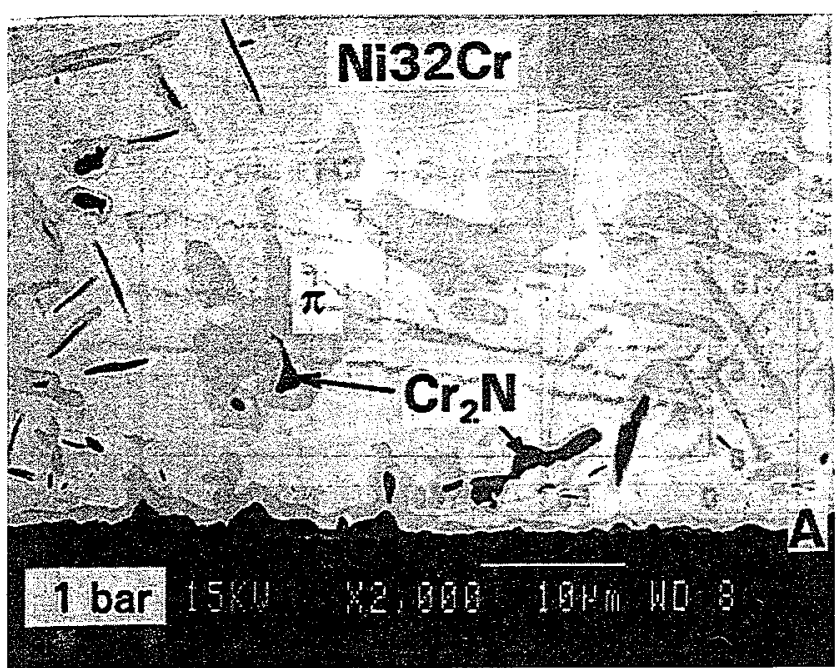

Pas

Fig. 10-The formation of the ternary $\pi$ phase of the $\mathrm{Ni}-\mathrm{Cr}-\mathrm{N}$ system in a $\mathrm{Ni}$ alloy with 32.0 at. pet of $\mathrm{Cr}$ after nitriding at $1398 \mathrm{~K}$ and $1 \mathrm{bar}$ of $\mathrm{N}_{2}$ for $16 \mathrm{~h}$ and slow cooling ( 75 to $300 \mathrm{deg} / \mathrm{h}$ ) at 1 bar of nitrogen. Backscattered electron image $(A=$ metal-gas interface)

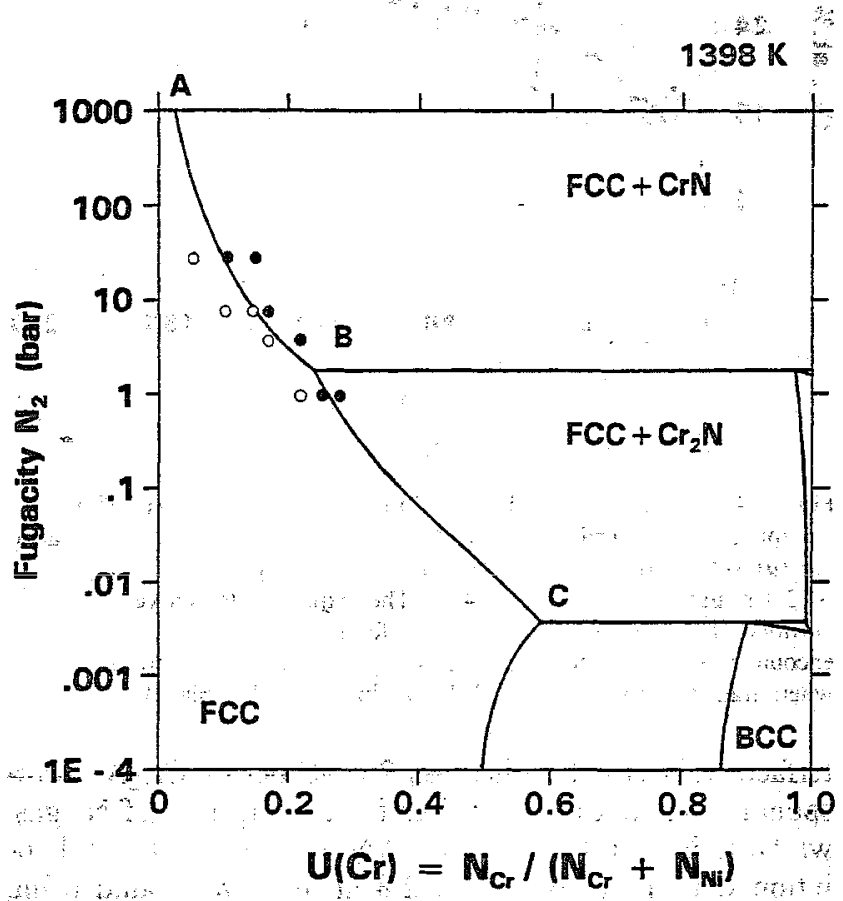

Fig. 11-Calculated stability diagram of chromium nitrides at $1398 \mathrm{~K}$ in various Ni-Cr alloys as a finction of the nitrogen fugacity together with experimental data (- chromium nitride was detected at the surface of alloy with XRD; o-no nitride formation).

interstitial solution model containing two sublattices was applied to all solid solution phases in which nitrogen is dissolved. ${ }^{[9]}$ The magnetic contribution is taken into account using Hillert and Jarl's $\mathrm{s}^{[10]}$ modification of the model for the magnetic Gibbs energy proposed by Inden. ${ }^{[1]}$ The magnetic contribution used herein is the one evaluated by Frisk [3]

The Ni-Cr-N system was reassessed in the present work by introducing a new binary parameter "which takes into account the interaction between $\mathrm{Ni}$ and $\mathrm{N}$ atoms in the facecentered cubic ( $\mathrm{fcc}$ ) solution and describes the excess Gibbs energy of the fcc phase. In order to reach the best agreement between the experimental and calculated values, the binary parameter was chosen to be equal to $-10.5 \mathrm{~kJ} / \mathrm{mol}$.

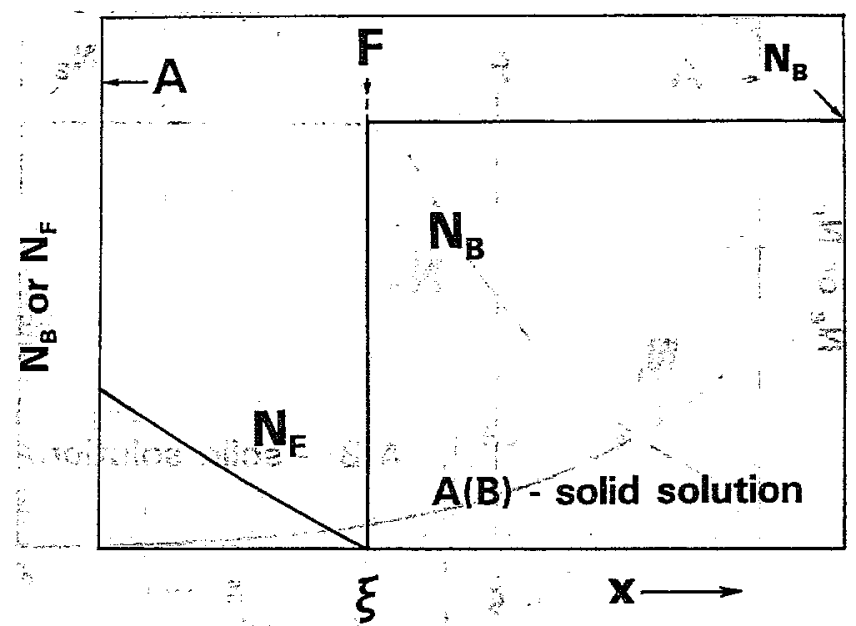

(a)

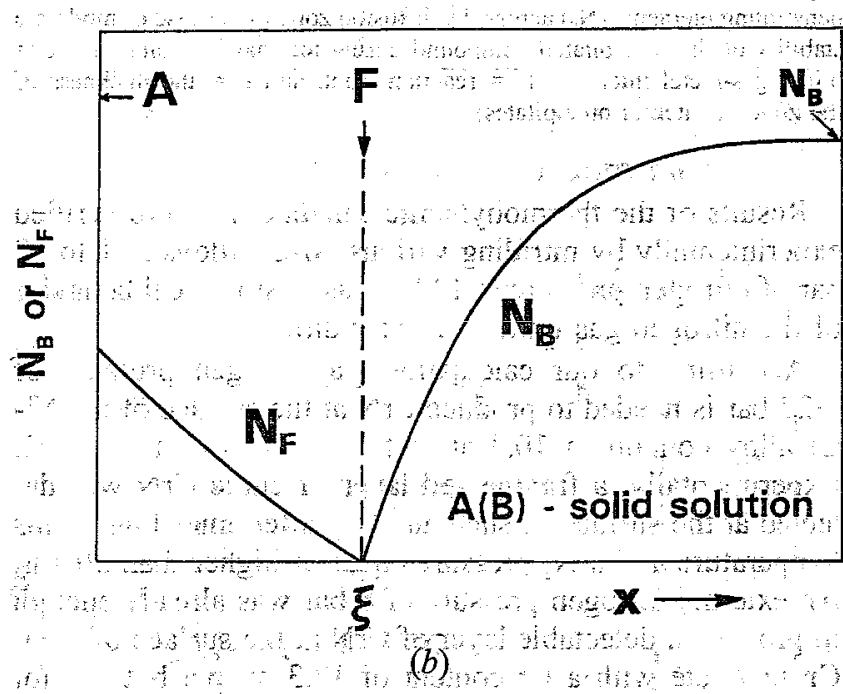

Fig. 12 Concentration profiles (schematically) for solite atoms $\left(\mathrm{N}_{\mathrm{B}}\right)$ and penetrating atoms $\left(\mathbb{N}_{F}\right)$ through the reaction zone during internal precipitation in the case of a low solubility product of the precipitated compound: (a) solute atoms are relatively immobile and $(b)$ solute diffises appreciably $(A=$ initial gas-metal interface, $F=$ reaction front, and $\xi=$ the thickness of the zone of internal precipitates).

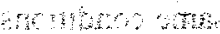

This is in the range of +20 to $-30 \mathrm{~kJ} / \mathrm{mol}$ which has been recently evaluated for the fcc phase in other $3 \mathrm{~d}$ transition metal-nitrogen systems $[7]$ is of of the

The calculated stability diagram of chromium nitrides at $1398 \mathrm{~K}$ in various $\mathrm{Ni}=\mathrm{Cr}$ alloys as a function of the nitrogen fugacity is given in Figure 11. The valuest of the nitrogen fugacity as a function of metal ratio $\left.U(C \mathrm{Cr})=N_{\mathrm{C}}\right)\left(\mathrm{A}_{\mathrm{Ni}}+\right.$ $N_{\mathrm{C} r}$ ) were calculated assuming that the molarivolumes of the condensed phases are independent of the external gas pressure âpplied upon the system. In fact, using this :graph; it is possible to predict which nitride phase will be formed at the metal-gás interface unider a certain external pressure (figacity) of nitrogen For example, the curve AB in Fig. 11 represents three-phase equilibria when $\mathrm{CrN}$ is in equit librium with the fec $\mathrm{Ni}=\mathrm{Cr}$ solid solution with a specified concentration of $\mathrm{Cr}$ and $\mathrm{N}_{2}$ gas pressure (fugacity). Similarly, the curve $\mathrm{BC}$ shows three-phase equilibria $\mathrm{Cr}_{2} \mathrm{~N}$ fcc $\mathrm{N}_{2}$ gas. Point $\mathrm{B}$ in this diagram displays a four-phase (invariant) equilibrium in the ternary $\mathrm{Ni}-\mathrm{Cr}-\mathrm{N}$ system at $1398 \mathrm{~K}$ who wh ate 


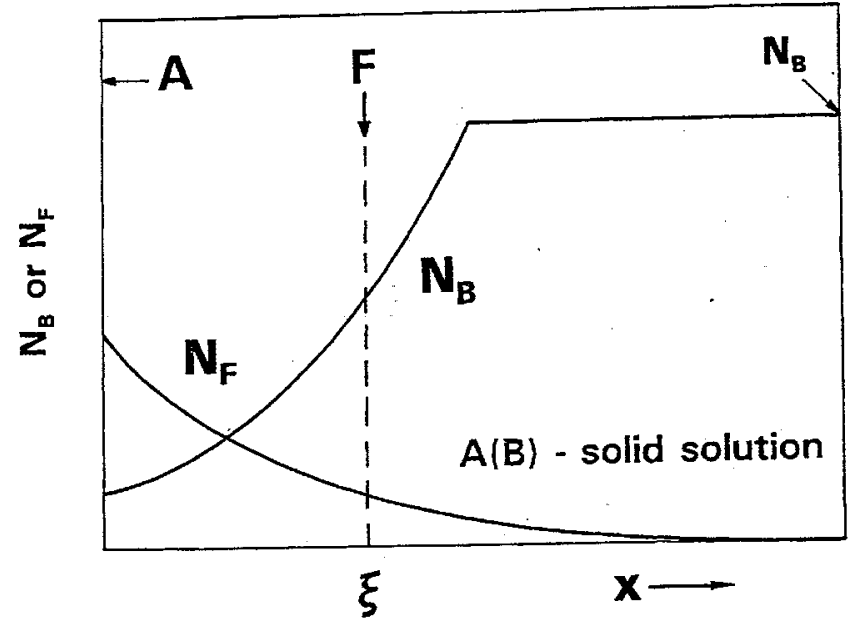

Fig. 13-Concentration profiles (schematically) for solute $\left(\mathrm{N}_{\mathrm{B}}\right)$ and penetrating elements $\left(\mathrm{N}_{\mathrm{F}}\right)$ across the diffusion zone in the case of moderate stability of the precipitated compound during internal precipitation $(\mathrm{A}=$ initial gas-metal interface, $\mathrm{F}=$ reaction front, and $\xi=$ the thickness of the zone of internal precipitates).

Results of the thermodynamic calculations were verified experimentally by nitriding various $\mathrm{Ni}-\mathrm{Cr}$ alloys at 1 to 40 bar of nitrogen pressure at $1398 \mathrm{~K}$ assuming ideal behavior of the nitrogen gas under these conditions.

According to our calculations, a nitrogen pressure of $\sim 27$ bar is needed to produce $\mathrm{CrN}$ at the surface of the $\mathrm{Ni}$ $\mathrm{Cr}$ alloy containing 10.4 at. pct of chromium at $1398 \mathrm{~K}$. Experimentally, a fragmented layer of cubic $\mathrm{CrN}$ was detected at the surface of such an alloy after annealing at this temperature and a $\mathrm{N}_{2}$ pressure equal or higher than 30 bar. An external nitrogen pressure of 8 bar was already enough to produce a detectable layer of $\mathrm{CrN}$ at the surface of a Ni$\mathrm{Cr}$ substrate with a $\mathrm{Cr}$ content of 17.3 at. pct but not for an alloy with only 15.0 at. pct of chromium. When using a nitrogen pressure of 4 bar at $1398 \mathrm{~K}$, the formation of cubic $\mathrm{CrN}$ was observed at the surface of the alloy with 22.0 at. pct of chromium. However, no positive indications of the reaction products at the interface gas- $\mathrm{Ni}-\mathrm{Cr}$ substrate with 17.3 at. pet of $\mathrm{Cr}$ were found after nitriding under the same conditions.

In order to check the calculated equilibrium line fcc + $\mathrm{Cr}_{2} \mathrm{~N}$ (Figure 11, curve BC), a number of $\mathrm{Ni}-\mathrm{Cr}$ alloys with relatively high (22.0 to 32.0 at. pct) concentrations of $\mathrm{Cr}$ were exposed to 1 bar pressure of nitrogen at $1398 \mathrm{~K}$ for 9 hours. Under these conditions, hexagonal $\mathrm{Cr}_{2} \mathrm{~N}$ was formed at the metal surface when the chromium content was 25.5 at. pct or higher. The results of the nitridation of the Ni-Cr alloys are depicted in Figure 11.

The correctness of the thermodynamic description used can be checked indirectly at a higher value of nitrogen fugacity as well. As was mentioned previously, exclusively internal nitrides were found inside the $\mathrm{Ni}-\mathrm{Cr}$ alloy with 5.0 at. pct of $\mathrm{Cr}$ after nitriding at $1398 \mathrm{~K}$ and 900 bar of $\mathrm{N}_{2}$. However, in some places of the reaction zone, the particles of $\mathrm{CrN}$ are in equilibrium with $\mathrm{Ni}-\mathrm{Cr}$ solid solution and $\mathrm{N}_{2}$ gas (Figure 5(a)). Composition of the Ni$\mathrm{Cr}$ solution, which is in equilibrium with $\mathrm{CrN}$ particles and $\mathrm{N}_{2}$ gas after nitriding under these conditions, can be estimated by extrapolation of the concentration profile of chromium across the diffusion zone to the metal-gas in-

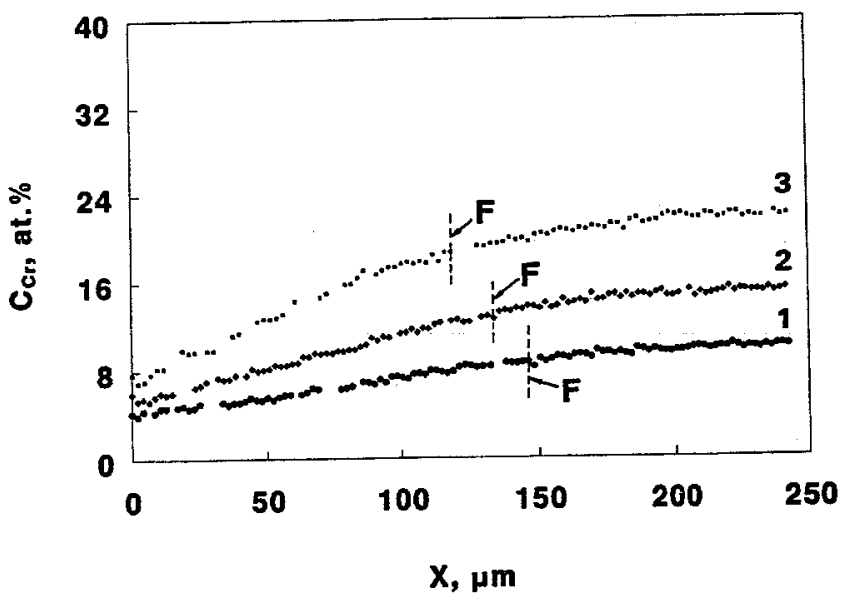

(a)

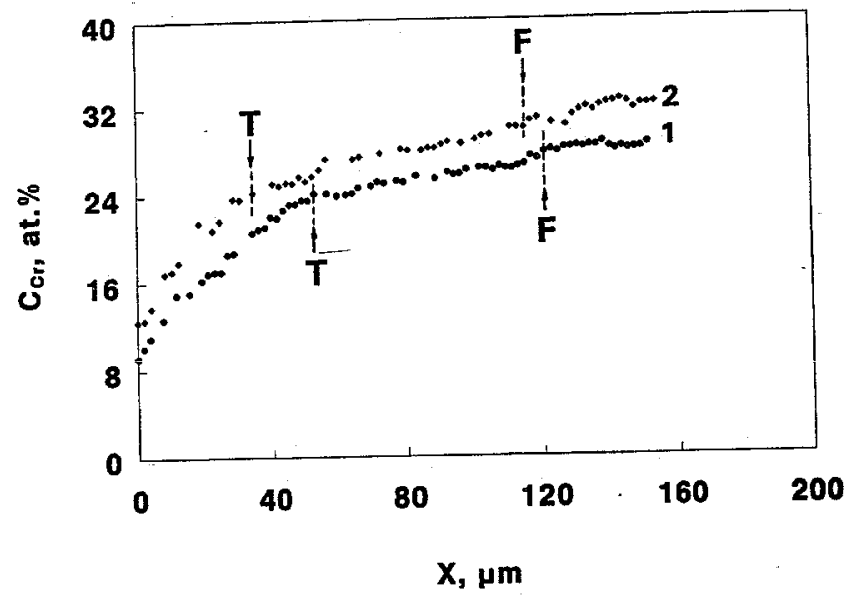

(b)

Fig. 14 Concentration profiles of chromium across the zone of internal precipitates after nitriding various $\mathrm{Ni}-\mathrm{Cr}$ alloys at $1398 \mathrm{~K}$ and 900 bar of $\mathrm{N}_{2}$ : (a) $1-\mathrm{Ni}-10 \mathrm{Cr}, 2-\mathrm{Ni}-15 \mathrm{Cr}$, and $3-\mathrm{Ni}-22 \mathrm{Cr}$ for $9 \mathrm{~h}$; and $(b) \mathrm{l}-$ $\mathrm{Ni}-28 \mathrm{Cr}$ and $2-\mathrm{Ni}-32 \mathrm{Cr}$ for $4 \mathrm{~h}$. The experimental curves represent portions of the profiles where no interference with nitride particles was encountered. $(F=$ reaction front, and $T=$ plane in the diffusion zone where transition from $\mathrm{CrN}$ to $\mathrm{Cr}_{2} \mathrm{~N}$ precipitation takes place).

terface. It was determined as 2.8 at. pct of Cr. A corresponding value of $\sim 1000$ bar for the fugacity of $\mathrm{N}_{2}$ gas, which is in equilibrium with $\mathrm{CrN}$ and an fcc $\mathrm{Ni}$ solid solution with a $\mathrm{Cr}$ content of 2.8 at. pct, was found using the calculated stability diagram. On the other hand, the fugacity of nitrogen at $1398 \mathrm{~K}$ and 900 bar pressure can be calculated using, for instance, the Peng-Robinson equation of state..$^{[12]}$ It gives the value $\sim 1070$ bar. Generally, the thermodynamic predictions are in good agreement with the experimental results.

\section{B. On the Diffusion of Nitrogen during the Internal Nitridation of $\mathrm{Ni}-\mathrm{Cr}$ Alloys}

The nitriding behavior of Ni-Cr alloys at $1398 \mathrm{~K}$ depends on the concentration of chromium in the initial alloy and the $\mathrm{N}_{2}$ pressure (fugacity) applied upon the system. One might expect a large gradient of nitrogen activity in the nitrided zone, especially in the possibly present surface nitride layer. Once formed, the surface layer grows slowly by the combination of outward diffusion of chromium from the matrix of the alloy and inward diffusion of nitrogen 
$1398 \mathrm{~K}$

1 bar $\mathrm{N}_{2}$

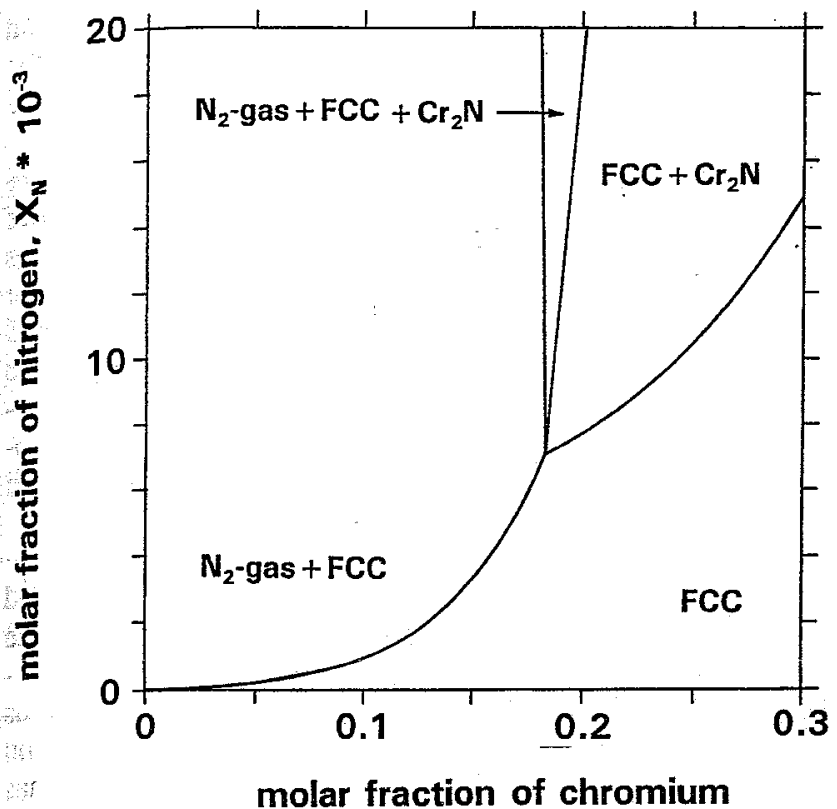

(a)

$1398 \mathrm{~K}$

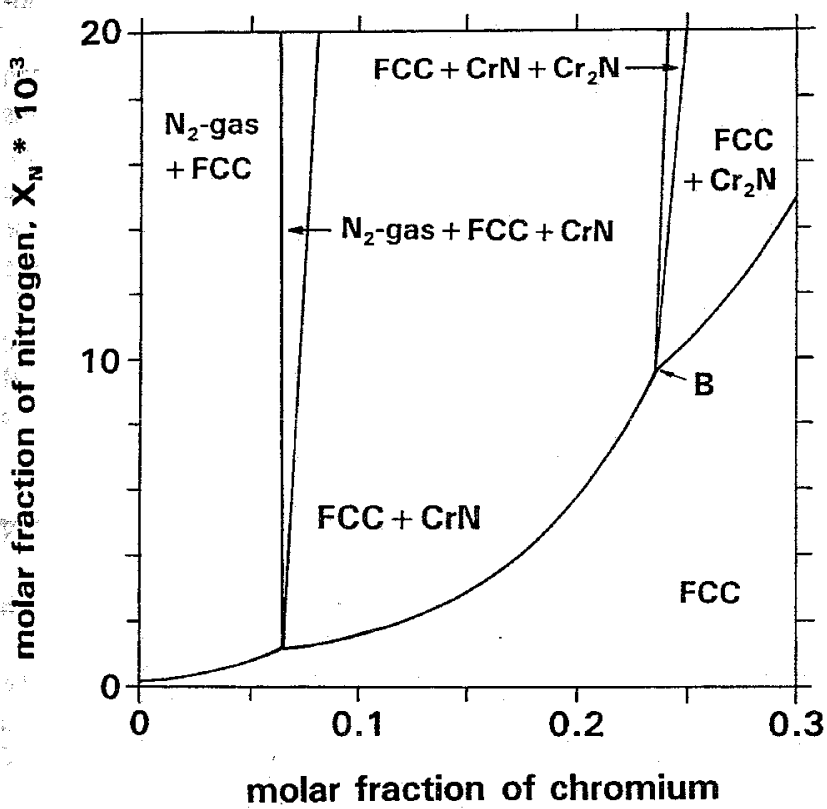

(c)

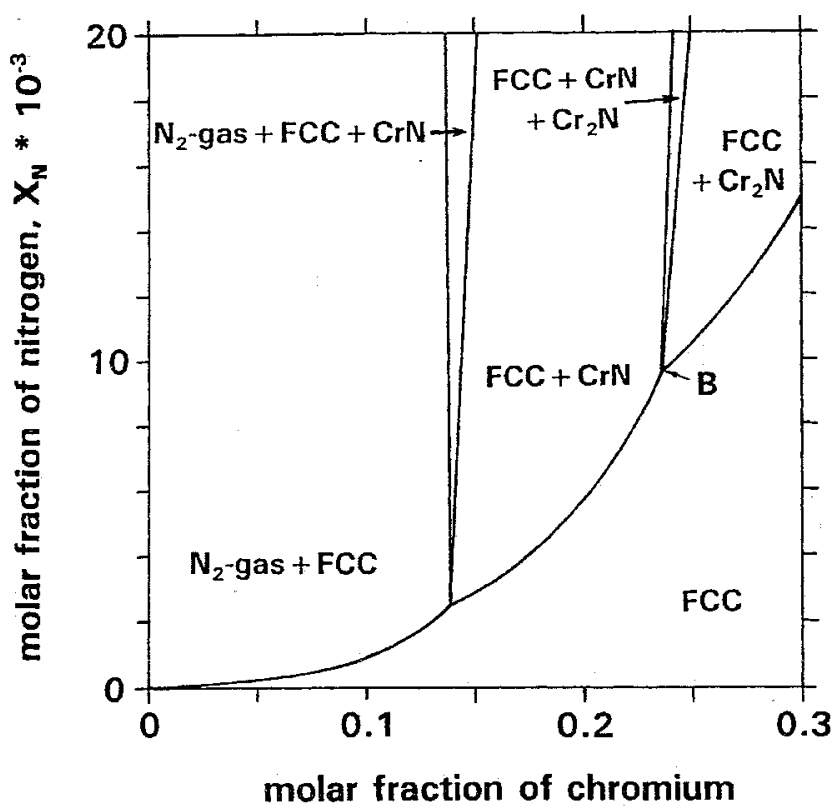

(b)

$1398 \mathrm{~K}$

1000 bar $\mathrm{N}_{2}$

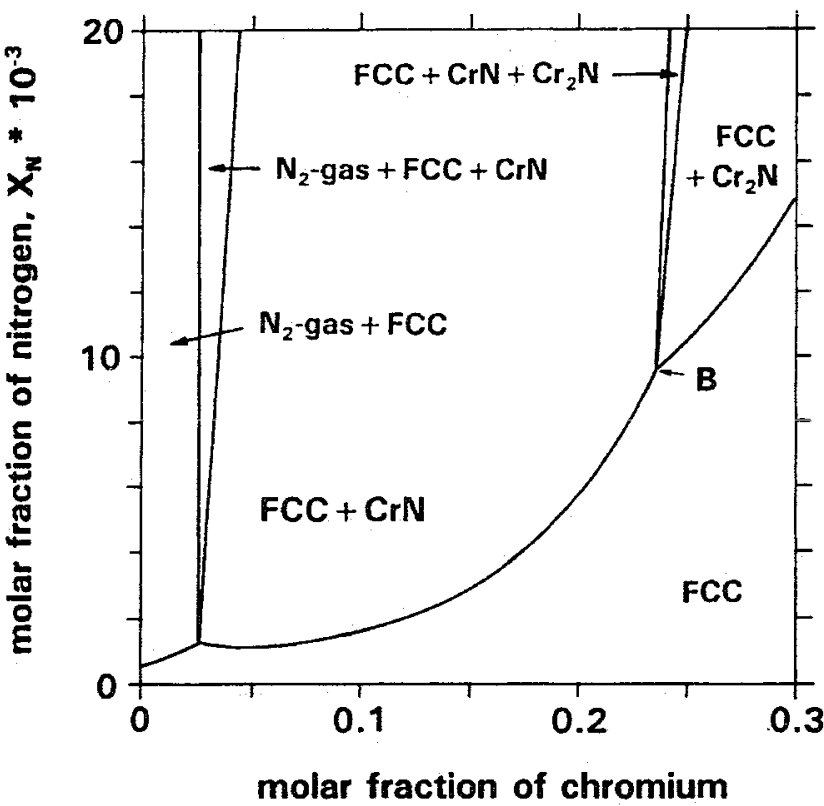

(d)

Fig. 15-Isothermal cross sections through the Ni-Cr-N system at $1398 \mathrm{~K}$ and various external pressure of $\mathrm{N}_{2}:(a) 1$ bar, $(b) 10$ bar, (c) 100 bar, and (d) 1000 bar.

through the surface nitride. In the latter case, a nitrogen activity inside the alloy is determined by its equilibrium value at the alloy/external nitride interface, rather than at the external surface. Such a reduction of the flux of nitrogen into the material can cause a difference in the precipitation process. For instance, the formation of $\mathrm{CrN}$ precipitates in the "corner" of the sample containing 32.0 at. pct of $\mathrm{Cr}$ after nitriding at 100 bar of nitrogen (Figure 4) is a result of the overlapping of fluxes of nitrogen atoms arriving from the two gas-metal interfaces which lead to an increasing nitrogen activity inside the alloy.
In general, the activity of nitrogen is decreased gradually toward the precipitation front. Grain boundary precipitation beyond the reaction front can be attributed to the fact that grain boundaries are preferred nucleation sites and chromium might be present in higher concentrations at grain boundaries due to segregation.

Two limiting cases of the formation of a zone of internal precipitates were identified. ${ }^{[13]}$ The first one is the classical internal precipitation process that can be associated with high stability (low solubility product) of the precipitating compounds. The theory of this phenomenon 

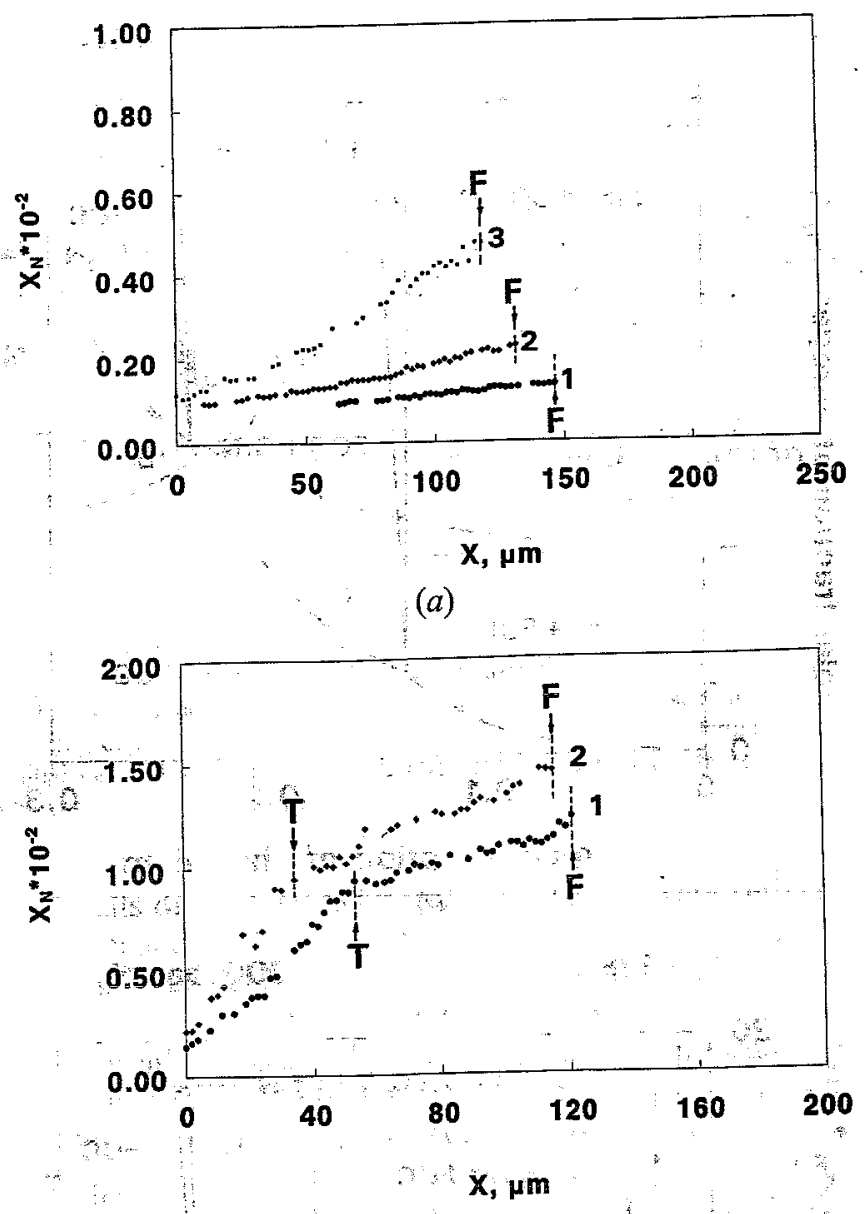

(b)

Fig. 16-Nitrogen concentration profiles through the matrix of the $\mathrm{NiE} \mathrm{Cr}$ solid solution within a zone of internal precipitates after nitriding various $\mathrm{Ni}-\mathrm{Cr}$ alloys at $1398 \mathrm{~K}$ and 900 bar of $\mathrm{N}_{2}$. (a) Diffusion zone consists of only $\mathrm{CrN}$ precipitates $(1-\mathrm{Ni}-10 \mathrm{Cr}, 2-\mathrm{Ni} 15 \mathrm{Cr}$, and $3-\mathrm{Ni}-22 \mathrm{Cr})$. (b) Transition from $\mathrm{CrN}$ to $\mathrm{Cr}_{2} \mathrm{~N}$ precipitates takes place within the nitrided zone (plane T) $(1-\mathrm{Ni}-28 \mathrm{Cr} ; 2-\mathrm{Ni}-32 \mathrm{Cr}$, and $\mathrm{F}=$ reaction front).

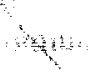

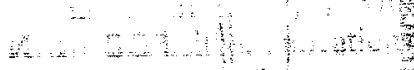

was developed by Wagner initially for internal oxidation, ${ }^{[141}$ and the present status was given by Rapp ${ }^{[15]}$ and Meijering. ${ }^{[16]}$

In the case of "classical Wagnerian behavior," the amount of precipitates across the reaction zone is constant and precipitation exclusively occurs at the reaction front. The very low solubility product of the precipitated compound implies that practically all solute is precipitated out in the precipitation zone. The activity of the penetrating element drops to a near-zero value at the reaction front. Depending on the relative mobility of the solute atoms, two types of concentration profiles through the diffusion zone can be derived (Eigures 12(a) and (b)).

The second limiting case implies that the precipitated compound has $\mathrm{a}^{- \text {" }}$ moderate" - stability. In this case, sprecipitation occurs continuously through the reaction zones The activity of the penetrating element does not approach a near-zero value at the reaction front and diffusion of this element continuous beyond the zone of internalprecipitates. Furthermore, the solute is not precipitated completely in the reaction zone. Recently, Christ ét al: ${ }^{[17]}$ made a computer simulation of the process of penetration of an element into an alloy connected with internal precipitation Computed concentration profiles for internal precipitation-type reactions with a moderate stability of precipitated compound were indeed somewhat similar to those supposed for the second limiting case by Laflamme and Morrall ${ }^{[13]}$ (Figure 13).

In the case of internal nitridation of $\mathrm{Ni}-\mathrm{Cr}$ alloys at 1398 $\mathrm{K}$ from a $\mathrm{N}_{2}$ gas atmosphere, a significant concentration of chromium in the fcc matrix within the zone of precipitates was found. As an example, the concentration profiles for chromium through the zone of internal precipitates formed during nitriding various $\mathrm{Ni}-\mathrm{Cr}$ alloys at $1398 \mathrm{~K}$ and 900 bar of $\mathrm{N}_{2}$ are given in Figures 14(a) and (b). These experimental curves represent portions of the concentration profiles across the nitrided zone where no interference with nitride particles was encountered.

Since chromium is not precipitated out entirely at the reaction. front, the nitrogen atoms diffuse in the nitrided zone not through a nearly pure Ni lattice but through the solid solution with certain concentration of chromium having a relatively high affinity for nitrogen. For diffusion, as well as for the estimated chemical activities, the interaction between $\mathrm{Cr}$ and nitrogen atoms in the Ni-based matrix has to be taken into consideration.

The effect of the presence of chromium in the Ni-based matrix on the thermodynamic behavior of nitrogen can be derived from the phase diagram. Using the same thermodynamic assessments as in the previous case, a number of isothermal cross sections through the Ni-Cr-N system can be calculated. In Figures 15(a) through (d), such diagrams at $1398 \mathrm{~K}$ and an external nitrogen pressure of $1,10,100$, and 1000 bar are given. Unfortunately, it was impossible to verify these calculated diagrams experimentally, because the concentration of nitrogen in the fcc solid solution was below the limit of detection in our analytical technique. However, the calculated concentration of chromium in fcc solid solution in equilibrium with $\mathrm{CrN}$ and $\mathrm{Cr}_{2} \mathrm{~N}$ (point $\mathrm{B}$ in Figures 15(b) through (d)) is 24.1 at. pct. This value is very close to that which was determined for the "triple" point within a reaction zone of a nitrided sample, where the $\mathrm{Ni}$-Cr solid solution was in equilibrium with both $\mathrm{CrN}$ and $\mathrm{Cr}_{2} \mathrm{~N}$ precipitates (Figures 4, 6, and 8(b)).

When the fec Ni-Cr solid solution is in equilibrium with $\mathrm{CrN}$ or $\mathrm{Cr}_{2} \mathrm{~N}$ precipitates, the values for $x_{N}^{f c c}$ and $x_{C r}^{f c c}$ are independent of the external $\mathrm{N}_{2}$ pressure applied upon the system (Figures 15(b) through (d)). The relations between $x_{N}^{f c c}$ and $x_{C r}^{f c c}$ in equilibrium with CrN precipitates at $1398 \mathrm{~K}$ were found as

$$
\ln x_{\mathrm{N}}=12.66 x_{\mathrm{Cr}}-7.71 \text { (for } 0.06<x_{\mathrm{Cr}}<0.241 \text { ) }
$$

The similar relations for the equilibrium fcc $+\mathrm{Cr}_{2} \mathrm{~N}$ precipitates were determined as

$$
\ln x_{\mathrm{N}}=7.46 x_{\mathrm{Cr}}-6.47 \text { (for } x_{\mathrm{Cr}}>0.241 \text { ) }
$$

Now, the experimental penetration curves for chromium (Figures 14(a) and (b)) across the internal nitrided precipitation zone can be converted into a nitrogen concentration profile through the matrix of $\mathrm{Ni}-\mathrm{Cr}$ solid solution within a reaction zone using the preceding equations (Figures 16(a) and (b)). This implies that in the Ni-based matrix, within the nitrided zone, nitrogen diffuses "up hill"' its own concentration gradient toward the precipitation front, although the activity of nitrogen decreases in that direction. Behind 
the precipitation front, the mole fraction of nitrogen must fall back to (in principle) a zero value at a large ("infinite") distance from the external surface.

Swisher ${ }^{[18]}$ also mentioned a somewhat similar behavior of a penetrating element forming internal precipitates. $\mathrm{He}$ found evidence for up hill diffusion of sulfur near the reaction front during the internal sulfidation of an $\mathrm{Fe}$ alloy with 0.38 wt pet of titanium at $1573 \mathrm{~K}$ in a $\mathrm{H}_{2} \mathrm{~S}+\mathrm{H}_{2}$ mixture. It was attributed to the relative instability of titanium sulfide and strong Ti-S interaction in the iron-based solid solution within the sulfidized zone.

\section{CONCEUSIONS}

When relatively unstable phases are precipitated out during internal precipitation reactions, the distribution of the various atoms within the diffusion zone can be predicted based on thermodynamic considerations of the respective systems. In this case, not only is a relative stability of the precipitated compound of importance but also the interaction between solute and penetrating atoms in the matrix of the solid solution within the precipitated zone must be taken into account.

In particular, attractive $\mathrm{Cr}-\mathrm{N}$ interaction in the fcc $\mathrm{Ni}-\mathrm{Cr}$ solid solution results in up hill diffusion of nitrogen through the Ni-based matrix toward the precipitation front. Such a behavior of nitrogen is opposite to the boundary conditions in Wagner's description of internal oxidation.

7. The experimental data on the equilibrium compositions of coexisting phases turned out to be consistent with the thermodynamic assessment of the $\mathrm{Ni}-\mathrm{Cr}-\mathrm{N}$ system.

\section{ACKNOWLEDGMENTS}

The authors are grateful to Dr. Bo Sundman, The Royal Institute of Technology (Stockholm, Sweden) for his advice concerning the use of the Thermo-Calc databank system.
This investigation was supported by the Netherlands Foundation for Chemical Research (SON) with financial aid from the Netherlands Organization for Scientific Research (NWO).

\section{REFERENCES}

1. J.J. Barnes and G.Y. Lai: Corrosion and Particle Erosion at High Temperature, Conf. Proc., Las Vegas, NV, 1989, V. Srinivasan and K. Vedula, eds., pp. 617-34.

2. R.P. Rubly and D.L. Douglass: Oxid. Met., 1991, vol. 35, pp. $259-$ 78.

3. G. Erdélyi, D.L. Beke, I. Gódény, L. Gergely, and F.J. Kedves: DIMETA-82 Diffusion in Metals and Alloys, [Proc. Int. Conf., Tihany, Hungary, Aug. 30-Sept. 3, 1982,] F.J. Kedves and D.L. Beke, eds., Trans Tech Publications, Aedermannsdorf, Switzerland, 1983 pp. 398400.

4. C.A. Wallace and R.C.C. Ward: J. Appl. Cryst., 1975, vol. 8, pp. 25560 .

5. M. Kikuchi, S. Wakita, and R. Tanaka: Trans. Iron Steel Inst. Jpn, 1973, vol. 13, pp. 226-28.

6. N. Ono, M. Kajihara, and M. Kikuchi: Metall. Trans. A, 1992, vol. 23A, pp. 1389-93.

7. K. Frisk: Ph.D. Thesis, Royal Institute of Technology, Stockholm, 1990.

8. A. Dinsdale: DMA(A) 195, National Physical Laboratory, London, 1990.

9. B. Sundman, B. Jansson, and J--O. Andersson: CALPHAD, 1985, vol. 9 , pp. $150-90$.

10. M. Hillert and M. Jarl: CALPHAD, 1978, vol. 2, pp. 227-38.

11. G. Inden: CALPHAD V, Project Meeting, Max Planck Institute, Eisenforschung, Düsseldorf, Federal Republic of Germany, 1976, vol. III (4) pp. 1-13.

12. S.I. Sandler: Chemical and Engineering Thermodynamics, John Wiley and Sons, New York, NY, 1989, pp. 181-84.

13. G.R. Laflamme and J.E. Morral: Acta Metall., 1978, vol. 26, pp. 179194.

14. C. Wagner: Z. Elektrochem., 1959, vol. 63, pp. 772-90.

15. R.A. Rapp: Corrosion, 1965 , vol. 21 , pp. $382-401$.

16. J.L.-Meijering: Advances in Materials Science, Herbert Herman, ed., Wiley-Interscience, New York, NY, 1971, pp. 1-81.

17. H.-J. Christ, H. Biermann, F.C. Rizzo, and H.G. Sockel: Oxid. Met., 1989, vol. 32, pp. 111-23.

18. J.H. Swisher: Trans. TMS-AIME, 1968, vol. 242, pp. 2433-39. 